volume in a paper on the maintenance of healthy fruit clones, by R. V. Harris. Dealing particularly with a nuclear stock organization for the propagation of tested healthy material, he shows that many fruit trees and plants harbour 'latent' viruses without showing symptoms. Strawberries have a high degree of tolerance in that they show little diminution of vigour when viruses are carried without causing symptoms. Raspberries and probably some tree fruits, on the other hand, often make but poor growth when 'latent' viruses are present-a previously unsuspected cause of lack of vigour. Absence of symptoms makes it impossible to maintain health by roguing alone; hence the necessity for a carefully controlled system of virus testing, the assessment of varietal reactions, and propagation under conditions where virus cannot be re-introduced.

D. W. Greenham describes several types of soil management for the fruit grower, from clean cultivation to permanent grass. $\mathrm{He}$ concludes that a suitable stand of grass and clover, mown frequently with a gang-machine, is in most cases the best form of soil management for English orchards. Straw mulches for soft fruit are also discussed; they are relatively non-absorbent, and appear to act as 'nonreturn valves' for the rainfall, and thereby conserve soil moisture, with considerable practical benefit.

Tree fruit yields fluctuate notoriously; A. P. Preston finds that thinning the fruits to one per twenty leaves gives good and regular crops. L. C. Luckwill shows that thinning on the large scale can be accomplished by spraying with $\alpha$-naphthalene acetic acid in concentrations ranging from 5 to 50 parts per million, depending on the variety, the time after petal-fall, the degree of thinning required, the temperature, and the nutritional status of the tree. He also discusses the now well-established use of the same substance for reducing fruit drops at various times. Changes in the orchard insect fauna during the present century are reviewed by A. M. Massee, who makes a plea for their ecological study as a whole. There are several other articles of more general or regional interest, and the excellent plates add lustre to a well-produced volume.

John Gratnger

\section{HUMAN BIOLOGY FOR THE MASSES}

Life, the Great Adventure

By Jean Rostand. (Discussions with Paul Bodin.) Translated by Alan Houghton Brodrick. Pp. 258. (London: Hutchinson's Scientific and Technical Publications, 1955.) 12s. 6d. net.

T HIS book is an account of a series of conversations on the French broadcasting system, which took place between Jean Rostand, a well-known French biologist and, like his famous father, a man of letters, and Paul Bodin, a distinguished poet, novelist, journalist and man of science. In the talks, Bodin played the part of a devil's advocate who was not ill-informed on matters which excite publio interest, while Rostand attempted to put the point of view of a modern biologist-philosopher on topics concerned with heredity, sex, health and the future of mankind. The radio talks were listened to by a large audience and have now been expanded by Rostand and Bodin into a book which is an admirable guide for those who wish to explore some of the broader paths in the field of current biology. Translation from the French has been made by A. H. Brodrick, himself well known for his contributions to the popularizing of science.

With Rostand's general point of view few modern biologists would quarrel, although his explanation of reasons for superfluous hair in the male is nonsense. Nor is he to be commended for the most obvious side-stepping of a question from Bodin dealing with birth control; perhaps, in France, the question should never have been put. This may also explain why a subject like miscegenation is dismissed in a sentence, although possibly here the translation may be at fault.

These, however, are trivial criticisms of a book which could reach many readers. Many of them will be shocked to learn that, in days of popular education and in a country like France, whose people are so proud of their ability to behave rationally, there are still about 3,460 astrologer-palmists in Paris alone. Here the man of science has cause to regret that the spread of scientific knowledge may even increase the credulity of those who possess a little scientific learning. One of the lessons from this book is that the mass of people are still prepared to believe anything, particularly if the new cult is served persuasively with the right amount of scientific jargon. Rostand and Bodin deserve praise for their efforts to remove some of the superstitions of 1955 .

T. H. HAwkINs

\section{HISTORY OF ASTRONOMY}

\section{The History of Astronomy}

By Prof. Giorgio Abetti. (Translated from the Italian "Storia dell' Astronomia" by Betty Burr Abetti.) Pp. xviii $+345+34$ plates. (London : Sidgwick and Jackson, Ltd., 1954.) 25s. net.

$\mathrm{TN}$ this book of more than three hundred pages Prof. G. Abetti gives the reader a straightforward summary of the history of astronomy. As he remarks in the preface, a book of this size "can be nothing but a summary of the vast amount of material which only a complete history could adequately present". He considers (Chapter 2) that the subject "may be arranged into three great periods corresponding to the history and civilization of the peoples of the Earth". First we have ancient astronomy, which can be traced back to about forty centuries before Christ and which can be considered to have ended with the decline of the Alexandrian school at about A.D. 650. Then comes medieval astronomy, which is mainly the astronomy of the Arabs and, to a small extent, that of the Romans. "But," comments Prof. Abetti, "the astronomy of these peoples, as also of the western Latins until Copernicus, is essentially nothing but a repetition of the Almagest of Ptolemy." Medieval astronomy is regarded by the author as extending up to about A.D. 1500. Between it and modern astronomy there is a transitional period of reformation, represented by the work of Copernicus, Tycho Brahe, Kepler, Galileo and Newton: "Through the work of these great men astronomy was launched on new and unthought-of paths to numerous and important conquests".

The modern era is considered to begin directly after Newton, and the book proceeds forward right up to the present day, Chapter 19 dealing with the 